\title{
Direction of Trade and Changing Export Pattern of Onion
}

\author{
A. R. Nalegaonkar ${ }^{1}$, S. S. More ${ }^{2}$, R. D. Shelke ${ }^{1 *}$ and P. A. Gade ${ }^{1}$ \\ ${ }^{1}$ Department of Agricultural Economics, College of Agricultural, Latur, India \\ ${ }^{2}$ Department of Agricultural Economics, College of Agricultural, Parbhani, India \\ *Corresponding author
}

\section{A B S T R A C T}

\section{Keywords}

Onion, Direction of trade, Markov chain analysis,

Transitional probability

\section{Article Info}

Accepted: 20 October 2020 Available Online: 10 November 2020
The origin of the onion is central Asia and west Pakistan. It probably acquired its name from the city built by ONIA in 1703 B.C. near gulf of Swez. Onion (Allium cepa) also known as bulb onion or common onion, is a vegetable crop that belongs to family Amaryllidaceae. There is a lot of demand of Indian Onion in the world, the country has exported 2182826.23 MT of fresh onion to the world for the worth of Rs. 3467.06 crore / 497.94 USD Millions during the year 2018-19. The export data of onion was collected for the HS code 07031010 . The secondary data of Onion export were collected for the period of 1996-97 to 2018-19. For the purpose of comparison, the period of study was divided into two sub periods, first period (from 1996-97 to 2007-08) and second period (2008-09 to 2018-19). To estimate the trade direction data were analyzed by using first order Markov chain. In the present study, Minimum Absolute Deviations (MAD) estimation procedure was employed to estimate the transitional probability. The result revels that, The direction of onion export was changed from period I to period II. As during the first period of study, Nepal was the most stable market followed by Singapore and Bangladesh and Pakistan was most unstable market. The direction of onion was completely changed during second period of study. In this period, Pakistan market was the most stable market for onion export followed by Bangladesh and Nepal.

\section{Introduction}

Onion (Allium cepa) also known as bulb onion or common onion, is a vegetable crop that belongs to family Amaryllidaceae and the most widely cultivated species of genus Allium. The origin of the onion is central Asia and west Pakistan. It probably acquired its name from the city built by ONIA in 1703 B.C. near gulf of Swez. Onion is an important horticultural commodities grown worldwide for their culinary purposes and medicinal values. One cup of chopped onion contains approximately 64 calories, $15 \mathrm{gm}$ of carbohydrate, $0 \mathrm{gm}$ of fat, $0 \mathrm{gm}$ of sugar, $2 \mathrm{gm}$ of protein and 10 percent or more of the daily value for vitamin c, vit-B-6. Onion contains antioxidants and compounds that fight inflammation decrease triglycerides and reduce cholesterol levels- all of which may lower heart disease risk.

In the year 2018-19 India exported 24,40,741.9 thousand MT of onion which has 
values of Rs 352205.34 Lakhs. India's export of onion was mainly to neighbouring south east Asian countries and some middle east nations. Malaysia, UAE, Sri Lanka, Bangladesh, Nepal, and Saudi Arabia account for the major share of exports from India. Bangladesh gives highest percent share in total export i.e. 30.50 per cent which gives value of 152.8 US\$ million followed by the Malaysia, United Arab Emits, Sri Lanka gives $14.92,10.75,10.35$ percent share in total export, which gives the value of 74.16, 53.49, 51.55 US\$ million. (sourcehttps://commerce-app.gov.in)

The main objectives of this study includes to study the direction of trade and changing export pattern of Onion

\section{Materials and Methods}

Direction of trade were studied for the country as a whole. The time series data were obtained for 23 years from the period 1996-97 to 201819. For the purpose of comparison, the period of study was divided into two sub periods, first period (from 1996-97 to 2007-08) and second period (2008-09 to 2018-19). The data on export quantity and value were collected from https://commerce-app.gov.in/ website and The Agricultural and Processed Food Products Export Development Authority (APEDA). The export data of onion was collected for the HS code 07031010. From the list of onion importers from India, top 13 countries, which were major and regular importers were identified and remaining countries were grouped as other countries. The top 13 countries were United Arab Emirates Malaysia, Sri Lanka, Bangladesh, Singapore, Saudi Arab, Kuwait, Pakistan, Qatar, Mauritius, Baharain, Indonesia. To estimate the trade direction data were analyzed by using first order Markov chain. In the present study, Minimum Absolute Deviations (MAD) estimation procedure was employed to estimate the transitional probability.

\section{Markov chain analysis}

The trade directions of export were analyzed using the first order Markov chain approach. Central to Markov chain analysis is the estimation of the transitional probability matrix $\mathrm{P}_{\mathrm{ij}}$. The elements $\mathrm{P}_{\mathrm{ij}}$ of the matrix $\mathrm{P}$ indicates the probability that export will switch from $i^{\text {th }}$ country to $j^{\text {th }}$ country with the passage of time (Dent, 1967; Lee et al 1970; Gillet, 1976). The diagonal elements of the matrix measure the probability that the export share of a country will be retained. Hence, an examination of the diagonal elements indicates the preference of an importing country to a particular country's exports. In the context of the current application, structural changes were treated as a random process with selected importing countries. The average exports to a particular country was considered to be a random variable which depends only on the past exports to that country, which can be denoted algebraically as

$\mathrm{E}_{\mathrm{jt}}=\sum_{\mathrm{i}=1}^{r} \mathrm{E}_{\mathrm{it}-1} \times \mathrm{P}_{\mathrm{ij}}+\mathrm{e}_{\mathrm{jt}}$

Where,

$E_{j t}=$ Exports from India to $j^{\text {th }}$ country during the year $\mathrm{t}$.

$E_{i t-1}=$ Exports from India to $i^{\text {th }}$ country during the period $\mathrm{t}-1$.

$\mathrm{P}_{\mathrm{ij}}=$ Probability that the exports will shift from $i^{\text {th }}$ country to $j^{\text {th }}$ country.

$\mathrm{E}_{\mathrm{jt}}=$ The error term which is statistically independent of $\mathrm{E}_{\mathrm{it}-1}$.

$\mathrm{t}=$ Number of years considered for the analysis 
$r=$ Number of importing countries

The transitional probabilities $\mathrm{P}_{\mathrm{ij}}$ which can be arranged in a (c x r) matrix have the following properties.

$\mathrm{O} \leq \mathrm{P}_{\mathrm{ij}} \leq 1$

$\sum_{j=1}^{r} \mathrm{P}_{\mathrm{ij}}=1$ for all $\mathrm{i}$

Thus, the expected export shares of each country during period " $\mathrm{t}$ " were obtained by multiplying the export to these countries in the previous period $(\mathrm{t}-1)$ with the transitional probability matrix.

\section{Estimation of the $\mathbf{P}_{\mathrm{ij}}$}

In the present study, Minimum Absolute Deviations (MAD) estimation procedure was employed to estimate the transitional probability, which minimizes the sum of absolute deviations (Fisher, 1961; Wagner, 1959). The conventional linear programming technique was used, as this satisfies the properties of transitional probabilities of nonnegativity restrictions and row sum constraints in estimation.

The linear programming formulation is stated as

Min $\mathrm{OP}^{*}+\mathrm{Ie}$

Subject to,

$\mathrm{XP}^{*}+\mathrm{V}=\mathrm{Y}$

$\mathrm{GP}^{*}=1$

$\mathrm{P}^{*} \mathrm{e} \geq 0$

Where,

$0=$ vector of zeroes.

$\mathrm{P}^{*}=$ vector in which probability $\mathrm{P}_{\mathrm{ij}}$ are arranged.

I = appropriate dimensioned column vector of units. $\mathrm{e}=$ vector of absolute error $(|\mathrm{U}|)$.

$\mathrm{Y}=$ vector of export to each country.

$\mathrm{X}=$ block diagonal matrix of lagged values of Y

$\mathrm{V}=$ vector of errors

$\mathrm{G}=$ grouping matrix to add the row elements of $\mathrm{P}$ as arranged in $\mathrm{P}^{*}$ to unity.

After calculating the transitional probability matrix, the expected shares of export were calculated by

$\mathrm{Y}_{\mathrm{jt}}=\sum_{j=1}^{r} y_{\mathrm{it}-1} \times \mathrm{P}_{\mathrm{ij}}(\mathrm{j}=1,2,3 \ldots \mathrm{r})$

Where,

$\mathrm{Y}_{\mathrm{jt}}=$ Predicted proportions of $\mathrm{j}^{\text {th }}$ country's share at time ' $t$ '.

$\mathrm{Y}_{\mathrm{t}-1}=$ Observed proportion of $\mathrm{i}^{\text {th }}$ country share at time 't-1'.

$\mathrm{P}_{\mathrm{ij}}=$ Estimated transitional probability matrix.

\section{Results and Discussion}

Trade direction of Onion export from India to major destinations during first period of study

The transitional probability matrix presented in table 1 provides a broad indication of changes in the direction of export of onion from India during the study period-I (1996-97 to 2007-08). Major onion importing countries were UAE, Malaysia, Sri Lanka, Bangladesh, Singapore, Kuwait, Pakistan, Nepal, Indonesia and all other importing countries were grouped under the category of the other countries. The transitional probability matrix was estimated for the study period-I by using the actual proportion of exports to different importing countries. This matrix explained changing direction of onion trade. The row elements in the transitional probability matrix provide the information on the extent of loss 
in trade, on account of competing countries. The columns element indicates the probability of gains in volume of trade from other competing countries and the diagonal element indicates probability of retention of the previous year's trade volume by the respective country.

Table.1 Trade direction of onion export from India to major destinations during first period of study

\begin{tabular}{|l|l|l|l|l|l|l|l|l|l|l|}
\hline Countries & UAE & Malaysia & $\begin{array}{c}\text { Sri } \\
\text { Lanka }\end{array}$ & Bangladesh & Singapore & Kuwait & Pakistan & Nepal & Indonesia & Other \\
\hline UAE & $\mathbf{0 . 3 4 0}$ & 0.160 & 0.329 & 0.035 & 0.006 & 0.011 & 0.000 & 0.000 & 0.000 & 0.120 \\
\hline Malaysia & 0.478 & $\mathbf{0 . 3 0 4}$ & 0.072 & 0.000 & 0.000 & 0.000 & 0.000 & 0.000 & 0.000 & 0.146 \\
\hline Sri Lanka & 0.000 & 0.474 & $\mathbf{0 . 3 1 1}$ & 0.164 & 0.048 & 0.000 & 0.000 & 0.000 & 0.003 & 0.000 \\
\hline Bangladesh & 0.000 & 0.229 & 0.086 & $\mathbf{0 . 5 9 0}$ & 0.000 & 0.002 & 0.032 & 0.002 & 0.000 & 0.059 \\
\hline Singapore & 0.323 & 0.000 & 0.000 & 0.000 & $\mathbf{0 . 6 3 8}$ & 0.000 & 0.000 & 0.000 & 0.039 & 0.000 \\
\hline Kuwait & 0.457 & 0.000 & 0.000 & 0.000 & 0.000 & $\mathbf{0 . 5 4 3}$ & 0.000 & 0.000 & 0.000 & 0.000 \\
\hline Pakistan & 0.000 & 0.000 & 0.000 & 0.673 & 0.000 & 0.023 & $\mathbf{0 . 0 0 0}$ & 0.004 & 0.036 & 0.265 \\
\hline Nepal & 0.000 & 0.000 & 0.000 & 0.155 & 0.000 & 0.000 & 0.000 & $\mathbf{0 . 8 4 5}$ & 0.000 & 0.000 \\
\hline Indonesia & 0.000 & 0.000 & 0.960 & 0.000 & 0.000 & 0.000 & 0.000 & 0.000 & $\mathbf{0 . 0 4 0}$ & 0.000 \\
\hline Other & 0.000 & 0.000 & 0.000 & 1.000 & 0.000 & 0.000 & 0.000 & 0.000 & 0.000 & $\mathbf{0 . 0 0 0}$ \\
\hline
\end{tabular}

Table.2 Trade direction of Onion export from India to major destinations during second period of study

\begin{tabular}{|l|l|l|l|l|l|l|l|l|l|l|}
\hline Countries & UAE & Malaysia & $\begin{array}{c}\text { Sri } \\
\text { Lanka }\end{array}$ & Bangladesh & Singapore & Kuwait & Pakistan & Nepal & Indonesia & Other \\
\hline UAE & $\mathbf{0 . 0 0 0}$ & 0.000 & 0.000 & 0.593 & 0.000 & 0.000 & 0.000 & 0.000 & 0.000 & 0.407 \\
\hline Malaysia & 0.322 & $\mathbf{0 . 4 0 2}$ & 0.164 & 0.000 & 0.061 & 0.013 & 0.000 & 0.000 & 0.037 & 0.002 \\
\hline Sri Lanka & 0.000 & 0.000 & $\mathbf{0 . 0 0 0}$ & 0.951 & 0.000 & 0.000 & 0.000 & 0.000 & 0.000 & 0.049 \\
\hline Bangladesh & 0.042 & 0.300 & 0.132 & $\mathbf{0 . 4 4 2}$ & 0.014 & 0.000 & 0.000 & 0.016 & 0.055 & 0.000 \\
\hline Singapore & 0.823 & 0.000 & 0.000 & 0.000 & $\mathbf{0 . 0 0 0}$ & 0.177 & 0.000 & 0.000 & 0.000 & 0.000 \\
\hline Kuwait & 0.000 & 0.000 & 0.000 & 0.000 & 0.000 & $\mathbf{0 . 0 0 0}$ & 0.000 & 0.855 & 0.000 & 0.145 \\
\hline Pakistan & 0.000 & 0.343 & 0.000 & 0.022 & 0.000 & 0.000 & $\mathbf{0 . 6 3 5}$ & 0.000 & 0.000 & 0.000 \\
\hline Nepal & 0.211 & 0.000 & 0.000 & 0.000 & 0.000 & 0.138 & 0.000 & $\mathbf{0 . 2 1 3}$ & 0.000 & 0.439 \\
\hline Indonesia & 0.000 & 0.000 & 0.530 & 0.000 & 0.102 & 0.038 & 0.000 & 0.000 & $\mathbf{0 . 1 1 2}$ & 0.219 \\
\hline Other & 0.160 & 0.000 & 0.104 & 0.000 & 0.000 & 0.094 & 0.000 & 0.088 & 0.067 & $\mathbf{0 . 4 8 8}$ \\
\hline
\end{tabular}

Among these countries, Nepal was one of the most stable markets among the major importers of onion from India as reflected by high probability of retention of 0.845 , i.e., the probability that Nepal retains the export share over the study was 84.5 per cent. Followed by Singapore retained (63.8 per cent) Bangladesh retained (59 per cent), Kuwait (54per cent), UAE (34 per cent), Sri Lanka (31 per cent),
Malaysia (30 per cent), Indonesia has less retention probability i.e.(4 per cent). Pakistan and other countries had a zero probability retention hence Pakistan and other countries were the most unstable market for onion export from India. From table 1 it is implied that, for the study period-I (1996-97 to 200607) Nepal was the most stable market for onion export followed by Singapore and 
Bangladesh, Kuwait. UAE, Sri Lanka, and Malaysia had moderately stable markets for onion export. The results of the study were in line with Sharma et al., (2016) and Beeraladinni et al., (2016).

Trade direction of Onion export from India to major destinations during second period of study

The transitional probability matrix presented in table 2 provides a broad indication of changes in the direction of export of onion from India during the study period-II (200809 to 2018-19). Major onion importing countries in second period were UAE, Malaysia, Sri Lanka, Bangladesh, Singapore, Kuwait, Pakistan, Nepal, Indonesia and all other importing countries were grouped under the category of the other countries. The transitional probability matrix was obtained for the study period-II by using the actual proportion of exports to different importing countries.

In period-II among these countries, Pakistan was one of the most stable markets among the major importers of onion from India as reflected by high probability of retention of 0.635 per cent, i.e., the probability that Pakistan retains the export share over the study was 63.50 per cent followed by other countries which retained (48.8per cent) Bangladesh retained (44.20 per cent) Malaysia (40.20 per cent) Nepal (21.30 per cent), Indonesia has less retention probability i.e. 11.20 per cent UAE, Sri Lanka, Kuwait, and Singapore had zero probability retention hence these countries had the most unstable market for onion export from India. From table 2 it was implied that during the study period-II (2007-08 to 2017-18) Pakistan was the most stable market for onion export followed by other countries, Bangladesh, Malaysia. Nepal and Indonesia were the moderately stable market for onion export.
UAE, Sri Lanka, Singapore and Kuwait are the most unstable market for onion export. The results of the study were in line with Kusuma and Kumara (2014) and Kusuma and Rudrapur (2016).

From the above results it is concluded that, the direction of onion export was changed from period I to period II. As during the first period of study, Nepal was the most stable market followed by Singapore and Bangladesh and Pakistan was most unstable market. The direction of onion was completely changed during second period of study. In this period, Pakistan market was the most stable market for onion export followed by Bangladesh and Nepal.

\section{References}

Beeraladinni, D., Lokesha, H. and J. B. Deshmanya (2016) Stability Analysis of India's Raw Cotton Exports. Indian Journal of Economics and Development, Vol. 12(4).

Dent, W.T. (1967) Application of Markov analysis to International Wool Flows, Rev. Econ. \& Statistics, Vol. 49 (2): 613-616.

Fisher, W.D. (1961) A Note on Curve Fitting with Minimum Deviation by Linear Programming, Journal of the American Statistical Association, Vol. 56(294): 359-362.

Gillet, B.E. (1976) Introduction of Operation Research. A computer oriented Algorithmic Approach, Magraw- Hill, New York, USA.

Kusuma, D.K. and B.R. Kumara (2014) Changing direction of Indian onion exports. International Journal of Agricultural Sciences, Vol.10 (1):198201.

Kusuma, D.K., and S. Rudrapur (2016) Production and export performance of Indian onion Markov chain analysis. 
Agriculture Update, Vol.11 (1): 70-74.

Lee, T.C., G.G. Judge and A. Zeellenner (1970)Estimating the parameters of the probability model from Aggregate Time Series data, North - Holland Publishing Company, Amsterdam.

Sharma, A., Ojha, A., Praveen K.V., Aditya

K.S, and P., Pokharna (2016)

International trade potential of Indian
Onion: an analysis of competitive advantage and direction of trade.

Wagnar, H.M. (1959) Linear programming Techniques for Regression Analysis, Journal of the American Statistical Association, Vol. 54(285): 206-212.

https://commerce-app.gov.in/

\section{How to cite this article:}

Nalegaonkar, A. R., S. S. More, R. D. Shelke and Gade, P. A. 2020. Direction of Trade and Changing Export Pattern of Onion. Int.J.Curr.Microbiol.App.Sci. 9(11): 2755-2760. doi: https://doi.org/10.20546/ijcmas.2020.911.334 